PIOTR KALKA

Wyższa Szkoła Finansów i Informatyki w Kaliszu

DOI : $10.14746 /$ rie.2019.13.18

\title{
Handel Polski z innymi państwami czlonkowskimi Unii Europejskiej (UE)
}

\section{Wstęp}

Przedmiot powyższego artykułu stanowi handel zagraniczny Polski z innymi państwami członkowskimi Unii. Pojęcie handlu zagranicznego ogranicza się tu do wymiany między państwami towarów. Pomija się natomiast wymianę usług.

Podjęcie tego rodzaju problematyki wynika z dwóch względów. Pierwszym jest istotne znaczenie, jakie może mieć handel zagraniczny we wzroście gospodarczym. Związane jest ono z rozwojem specjalizacji. Drugi wzgląd to brak aktualnych opracowań na temat handlu zagranicznego Polski z innymi państwami członkowskimi Unii ${ }^{1}$.

Przeprowadzona w artykule analiza ma cztery cele. Pierwszym jest określenie tempa wzrostu handlu Polski z innymi krajami członkowskimi Unii Europeskiej, jak i pokazanie uwarunkowań tego wzrostu. Pokazane jest przy tym tempo wzrostu handlu tak w wartościach nominalnych, jak i realnych. Dalszy cel to przedstawienie struktury geograficznej tego rodzaju wymiany handlowej oraz jej uwarunkowań, a kolejny polega na ukazaniu struktury rzeczowej wymiany handlowej Polski z pozostałymi krajami Unii Europejskiej oraz jej przyczyn. Czwarty cel to pokazanie salda handlowego we wzajemnym handlu. Te dwa ostatnie cele będą analizowane z uwzględnieniem produktów wysokiej i średnio-wysokiej techniki oraz produktów niskiej i średnio-niskiej techniki². Analiza obejmie okres 2005 (2007)-2017.

\section{Rozwój handlu Polski z pozostałymi krajami członkowskimi Unii Europejskiej}

Handel ten rozwijał się w cenach rynkowych dynamicznie. W latach 2006-2017 eksport wzrastał przeciętnie o $10,0 \%$, a import - o $8,1 \%$. W cenach stałych tempo

${ }^{1}$ Najważniejsza z tych prac to: J. Misala, E. Pluciński, Handel wewnątrzgałęziowy między Polska a Unia Europejska: teoria i praktyka, Dom Wydawniczy Elipsa, Warszawa 2000.

${ }^{2}$ Produkty wysokiej techniki prezentują najwyższy udział wydatków badawczo-rozwojowych w obrocie firm, czyli wykazują największą intensywność badawczo-rozwojową. Należą do nich np. komputery, wyroby elektroniczne i optyczne. Wyroby średnio-wysokiej techniki mają niższą intensywność badawczo-rozwojową i dotyczą zwłaszcza pojazdów samochodowych, lokomotyw kolejowych, wojskowych pojazdów bojowych, sprzętu transportowego, urządzeń i produktów medycznych. Dwa pozostałe rodzaje produktów obejmują m.in. wytwarzany albo przetwarzany koks, wyroby z gumy i tworzyw sztucznych, artykuły spożywcze, napoje, wyroby tekstylne, papier i wyroby z papieru oraz meble. Charakterystyczna jest dla tych dwóch rodzajów produktów niska intensywność badawczo-rozwojowa (Nauka i technika w 2016 r. Aneks VI). 
wzrostu handlu było jednak znacznie niższe. I tak eksport zwiększał się (w cenach z 1995 r) w latach 2006-2016 średnio o 2,5\%, a import - o 1,0\% (patrz tabela 1).

W 2009 r. doszło do istotnego spadku tempa wzrostu eksportu i importu. Obydwie te wielkości zamykały się (w cenach stałych) wartościami ujemnymi. Z kolei w latach 2012-2016 zarówno eksport, jak i import kształtowały się w tych cenach na poziomie ujemnym albo stosunkowo niskim.

Rodzić się tu muszą dwa pytania. Są one następujące:

- dlaczego w 2009 r. tempo wzrostu eksportu i importu było (w cenach stałych) ujemne?

- jakie przyczyny powodowały, że tempo to sięgało w latach 2012-2016 wartości ujemnych albo dość niskich?

W 2009 r. spadł światowy produkt krajowy brutto (PKB). Obniżył się on o -3,5\%, przy czym spadek produktu krajowego brutto piętnastu państw członkowskich Unii wynosił -4,2\% (Boysen-Hochgrefe et al., 2010, s. 15 i 20). Rządy i banki emisyjne próbowały stabilizować sektor bankowy i pobudzać koniunkturę. Nie dawało to jednak efektów (Boysen-Hochgrefe et al., 2010, s. 15 i 20; Gern et al., 2009, s. 3). Konsekwencją spadku światowego PKB, a zwłaszcza dotyczącego państw Unii Europejskiej było istotne obniżenie tempa wzrostu eksportu do tych państw. Jednocześnie jego obniżenie przyczyniało się do ograniczenia importu. W eksporcie Polska wykorzystywała bowiem w znacznej mierze elementy importowane.

Pod wpływem mało dynamicznego rozwoju realnego produktu krajowego brutto w Unii Europejskiej nastąpił nieznaczny wzrost eksportu Polski do państw członkowskich Unii, wynoszący średnio w latach 2012-2016 0,5\%3. Trzeba tu podkreślić, że ten mało dynamiczny rozwój realnego PKB pozostawał w ścisłym związku z kryzysem w strefie euro. Kryzys wyrażał się w zasadniczych trudnościach ekonomicznych takich państw jak Grecja, Hiszpania, Irlandia i Portugalia, a wyrażających się w istnieniu zbyt wysokiego deficytu budżetowego, występowaniu problemów finansowych w bankach oraz w niełatwej spłacie pożyczek.

Tabela 1

Wielkość i tempo wzrostu handlu Polski z pozostałymi krajami czlonkowskimi Unii Europejskiej

a)

\begin{tabular}{||c|c|c|c|c||}
\hline Rok & $\begin{array}{c}\text { Eksport Polski do } \\
\text { państw czlonkowskich } \\
\text { Unii w mln euro } \\
\text { (w cenach rynkowych) }\end{array}$ & $\begin{array}{c}\text { Tempo wzrostu } \\
\text { eksportu (w \%) }\end{array}$ & $\begin{array}{c}\text { Import Polski z krajów } \\
\text { Unii w mln euro } \\
\text { (w cenach rynkowych) }\end{array}$ & $\begin{array}{c}\text { Tempo wzrostu } \\
\text { importu (\%) }\end{array}$ \\
\hline 1 & 2 & 3 & 4 & 5 \\
\hline 2005 & 55136 & $\cdot$ & 53200 & 20,3 \\
\hline 2006 & 68079 & 23,5 & 63997 & 20,7 \\
\hline 2007 & 80316 & 18,0 & 77240 & 14,2 \\
\hline 2008 & 90457 & 12,6 & 88171 & $-24,5$ \\
\hline 2009 & 78231 & $-13,5$ & 66531 &. \\
\hline
\end{tabular}

3 Tempo wzrostu realnego PKB 15 państw członkowskich Unii sięgało w $2012-0,4 \%$; 2013 $-0,1 \% ; 2014-0,9 \%, 2015-1,6 \%$ i (w przybliżeniu) w 2016 r. -1,6\% (K.-J. Gern et al., 2013, s. 30; K.-J. Gern et al., 2014, s. 22; Grundlinien, 2016, s. 524). 


\begin{tabular}{||c|c|c|c|c||}
\hline 1 & 2 & 3 & 4 & 5 \\
\hline 2010 & 95286 & 21,8 & 79849 & 20,0 \\
\hline 2011 & 106620 & 11,9 & 91043 & 14,0 \\
\hline 2012 & 109880 & 2,3 & 88581 & $-2,7$ \\
\hline 2013 & 116293 & 6,6 & 91804 & 2,8 \\
\hline 2014 & 128398 & 10,4 & 99457 & 9,2 \\
\hline 2015 & 142543 & 11,0 & 106375 & 7,00 \\
\hline 2016 & 147564 & 3,5 & 110819 & 4,2 \\
\hline 2017 & 165390 & 12,1 & 124437 & 12,3 \\
\hline $2006-2017$ & - & 10,0 & - & 8,1 \\
\hline
\end{tabular}

Żródla: Główny Urząd Statystyczny, Rocznik Statystyczny Handlu Zagranicznego 2007, s. 55-57; 2008, s. 55-57; 2010, s. 57-59; 2016, s. 65-67; 2017, s. 63-65; 2018, s. 57-59; obliczenia własne.

b)

\begin{tabular}{|c|c|c|c|c|}
\hline Rok & $\begin{array}{c}\text { Eksport Polski do } \\
\text { państw czlonkowskich } \\
\text { Unii (w cenach stałych } \\
\text { z } 1995 \text { r.) }\end{array}$ & \begin{tabular}{|c|} 
Tempo wzrostu \\
eksportu w cenach \\
stałych $\mathrm{z} 1995 \mathrm{r}$. \\
$(\%)$
\end{tabular} & $\begin{array}{c}\text { Import Polski z państw } \\
\text { członkowskich Unii } \\
\text { (w cenach stałych } \\
\text { z } 1995 \text { r.) }\end{array}$ & \begin{tabular}{|c|} 
Tempo wzrostu \\
importu w ce- \\
nach stalych \\
z 1995 r. (\%)
\end{tabular} \\
\hline 2005 & 16825 & . & 17386 & . \\
\hline 2006 & 17892 & 6,3 & 17906 & 3,0 \\
\hline 2007 & 19293 & 7,8 & 18775 & 4,9 \\
\hline 2008 & 20346 & 5,5 & 19752 & 5,2 \\
\hline 2009 & 19127 & $-6,0$ & 17389 & $-12,0$ \\
\hline 2010 & 20580 & 7,6 & 18356 & 5,6 \\
\hline 2011 & 21303 & 3,5 & 19706 & 7,4 \\
\hline 2012 & 21233 & $-0,3$ & 19464 & $-1,2$ \\
\hline 2013 & 21102 & $-0,6$ & 19604 & 0,7 \\
\hline 2014 & 21836 & 3,5 & 19237 & $-1,9$ \\
\hline 2015 & 22508 & 3,1 & 19540 & 1,6 \\
\hline 2016 & 21839 & $-3,0$ & 19133 & $-2,1$ \\
\hline 2017 & $39435^{a}$ & . & $40258^{\mathrm{a}}$ & \\
\hline $\begin{array}{l}\text { 2006-2016 } \\
\text { (średnia } \\
\text { w tempie } \\
\text { wzrostu) }\end{array}$ & & 2,5 & & 1,0 \\
\hline
\end{tabular}

Wyjaśnienia: a dane są wyrażone w cenach z 2000 r.

Źródła: Główny Urząd Statystyczny, Rocznik Statystyczny Handlu Zagranicznego 2007, s. 55-57; 2008, s. 55-57; 2010, s. 57-59; 2016, s. 65-67; 2017, s. 48, 63-65; 2018, s. 43, 57-59; obliczenia własne.

Na skutek kryzysu z rynków pożyczkowych tych państw wycofywali się inwestorzy, a banki organiczały wzajemne finansowanie. Dotyczyło to również działań banków amerykańskich w stosunku do europejskich. Jednocześnie programy pomocy dla Irlandii i Portugalii przewidywały m.in. zwiększenie podatków (Axt, 2010, s. 21; Kalka, 2012, s. 152).

Z kolei słaby wzrost eksportu Polski do krajów członkowskich Unii był jednym z uwarunkowań spadku importu RP z tej strefy. 


\section{Struktura geograficzna eksportu i importu z Polski/do Unii Europejskiej}

Decydującą rolę w obrotach handlowych Polski z państwami członkowskimi Unii odgrywała Republika Federalna Niemiec. Zaznaczyła się jednocześnie tendencja do pewnego zwiększenia tej roli (patrz tabela 2).

O szczególnym znaczeniu Republiki Federalnej zdecydowały zwłaszcza dwa czynniki. Pierwszy stanowiło przywiązywanie przez polskich przedsiębiorców szczególnej wagi do stosowania niemieckich technologii. Nie było to zjawisko nowe. Występowało ono już przed II wojną światową i odrodziło się po 1989 r. po okresie supremacji techniki radzieckiej. Już w 1990 r. RFN stała się najważniejszym eksporterem towarów do Polski.

Drugim czynnikiem były bezpośrednie inwestycje kapitału niemieckiego na terenie Polski. ${ }^{4}$ Łącznie jej zobowiązania z tytułu zagranicznych inwestycji bezpośrednich wyniosły do końca 2017 r. 830,2 mld zł, z czego 17,6\% przypadało na Niemcy. Zajmowały one pod tym względem drugie miejsce, za Holandią. Holandii dotyczyło 19,2\% tego rodzaju zobowiązań (Narodowy Bank Polski, 2017).

Bezpośrednie inwestycje zagraniczne powodują dwa następujące skutki. Po pierwsze, przedsiębiorstwa z udziałem kapitału zagranicznego zaopatrują się głównie w dobra inwestycyjne i materiały w swym kraju macierzystym. W literaturze naukowej ocenia się, że zainwestowanie 100 jednostek kapitału zagranicznego powoduje import ze strony państwa przyjmującego inwestycje o wielkości odpowiadającej 40 jednostkom (Deficyt $w$ handllu, 1998, s. 18). Po drugie, firmy z kapitałem zagranicznym wysyłają wytwarzane produkty w większym czy mniejszym stopniu do kraju swego pochodzenia.

Obok Republiki Federalnej największymi eksporterami i importerami do/i z Polski były Włochy, Francja, Republika Czeska, Holandia i Wielka Brytania (patrz tabela 2).

Tabela 2

Najwięksi eksporterzy i importerzy z/i do Polski z Unii Europejskiej

\begin{tabular}{||c|c|c|c||}
\hline \hline $\begin{array}{c}\text { Państwo czlonkowskie } \\
\text { Unii Europejskiej }\end{array}$ & Rok & $\begin{array}{c}\text { Udzial Polski w imporcie } \\
\mathbf{z ~ U E ~} \mathbf{( \% )}\end{array}$ & $\begin{array}{c}\text { Udzial Polski w eksporcie } \\
\mathbf{d o} \text { UE (w \%) }\end{array}$ \\
\hline \multicolumn{1}{|c|}{$\begin{array}{c}\text { Republika Federalna } \\
\text { Niemiec }\end{array}$} & 2 & 3 & 4 \\
\cline { 2 - 4 } & 2005 & - & - \\
\cline { 2 - 4 } & 2008 & 37,1 & 32,2 \\
\cline { 2 - 4 } & 2011 & 37,4 & 33,4 \\
\cline { 2 - 4 } & 2014 & 37,3 & 34,0 \\
\hline \multirow{3}{*}{ Włochy } & 2005 & 38,3 & 34,3 \\
\cline { 2 - 4 } & 2008 & - & - \\
\cline { 2 - 4 } & 2011 & 10,5 & 7,7 \\
\cline { 2 - 4 } & 2014 & 9,0 & 6,8 \\
\cline { 2 - 4 } & 2017 & 9,6 & 5,9 \\
\hline
\end{tabular}

${ }^{4}$ Przez bezpośrednie inwestycje zagraniczne (BIZ) rozumie się podejmowanie od podstaw samodzielnej działalności gospodarczej za granicą lub przejmowanie kierownictwa już istniejącego przedsiębiorstwa (por. Budnikowski, 2006, s. 144). 


\begin{tabular}{|c|c|c|c|}
\hline 1 & 2 & 3 & 4 \\
\hline \multirow[t]{5}{*}{ Francja } & 2005 & - & - \\
\hline & 2008 & 7,6 & 8,0 \\
\hline & 2011 & 7,0 & 7,9 \\
\hline & 2014 & 6,3 & 7,2 \\
\hline & 2017 & 6,4 & 7,0 \\
\hline \multirow[t]{5}{*}{ Republika Czeska } & 2005 & - & - \\
\hline & 2008 & 5,8 & 7,3 \\
\hline & 2011 & 6,2 & 8,0 \\
\hline & 2014 & 6,1 & 8,3 \\
\hline & 2017 & 6,0 & 8,0 \\
\hline \multirow[t]{5}{*}{ Holandia } & 2005 & - & - \\
\hline & 2008 & 5,6 & 5,2 \\
\hline & 2011 & 6,3 & 5,6 \\
\hline & 2014 & 6,4 & 5,4 \\
\hline & 2017 & 6,3 & 5,0 \\
\hline \multirow[t]{5}{*}{ W. Brytania } & 2005 & - & - \\
\hline & 2008 & 4,6 & 7,4 \\
\hline & 2011 & 4,4 & 8,3 \\
\hline & 2014 & 4,4 & 8,2 \\
\hline & 2017 & 4,0 & 8,0 \\
\hline
\end{tabular}

Źrodło: Główny Urząd Statystyczny, Rocznik Statystyczny Handlu Zagranicznego 2009, s. 55; 2012, s. 61; 2015, s. 63; 2018, s. 55.

\section{Struktura rzeczowa handlu Polski z pozostałymi krajami czlonkowskimi Unii Europejskiej}

W imporcie Polski z tych krajów znaczny udział, bo co najmniej 48,8\% stanowiły w latach 2007, 2011, 2014 i 2017 wyroby o wysokiej i średnio-wysokiej technice (patrz tabela 3). Dostarczały ich takie gałęzie, jak przemysł chemiczny, maszynowy, elektrotechniczny, przemysły wytwarzające sprzęt transportowy, przyrządy i aparatury (fotograficzne, pomiarowe, kontrolne i optyczne etc.) oraz broń i amunicję.

W eksporcie Polski do innych krajów członkowskich Unii na produkty o wysokiej i średnio-wysokiej technice przypadała w latach 2007, 2011, 2014 i 2017 nieco niższa część całości wywożonych towarów jak w imporcie (patrz tabela 3).

\section{Struktura rzeczowa handlu Polski z państwami członkowskimi UE}

a)

\begin{tabular}{||c|c|c|c|c||}
\hline \multirow{2}{*}{ Nazwa wyrobu } & \multicolumn{4}{c|}{$\begin{array}{c}\text { Udział w całości importu z państw } \\
\text { czlonkowskich UE (w \%) }\end{array}$} \\
\cline { 2 - 5 } & $\mathbf{2 0 0 7}$ & $\mathbf{2 0 1 1}$ & $\mathbf{2 0 1 4}$ & $\mathbf{2 0 1 7}$ \\
\hline 1 & 2 & 3 & 4 & \multicolumn{1}{|c|}{5} \\
\hline I) wyroby niskiej i średnioniskiej techniki & 49,2 & 50,6 & 50,8 & 49,6 \\
\hline - zwierzęta żywe; produkty pochodzenia zwierzęcego & 1,4 & 2,6 & 3,4 & 3,3 \\
\hline - produkty pochodzenia roślinnego & 2,3 & 2,6 & 2,4 & 2,6 \\
\hline
\end{tabular}




\begin{tabular}{|c|c|c|c|c|}
\hline 1 & 2 & 3 & 4 & 5 \\
\hline - thuszcze i oleje & 0,4 & 0,7 & 0.7 & 0,7 \\
\hline - przetwory spożywcze & 2,9 & 3,8 & 4,1 & 4,4 \\
\hline - produkty mineralne & 4,5 & 4,4 & 3,2 & 2,6 \\
\hline - tworzywa sztuczne i kauczuk oraz artykuły z nich & 9,6 & 10,4 & 10,4 & 10,2 \\
\hline - skóry i artykuły z nich & 0,7 & 0,5 & 0,6 & 0,6 \\
\hline - drewno i artykuły z drewna & 1,1 & 1,0 & 0,9 & 0,7 \\
\hline - ścier drzewny, papier, tektura i artykuły z nich & 3,8 & 4,0 & 3,9 & 4,0 \\
\hline - materiały i artykuły włókiennicze & 3,9 & 3,1 & 3,3 & 3,1 \\
\hline - obuwie, nakrycia głowy & 0,2 & 0,3 & 0,4 & 0,5 \\
\hline - artykuły z kamienia, wyroby ceramiczne, szkło & 1,8 & 1,5 & 1,4 & 1,3 \\
\hline $\begin{array}{l}\text { - perły, kamienie szlachetne, metale szlachetne i wyroby } \\
\text { z nich }\end{array}$ & 0,3 & 0,2 & 0,2 & 0,4 \\
\hline - metale nieszlachetne i wyroby $\mathrm{z}$ nich & 14,7 & 14,0 & 13,2 & 13,9 \\
\hline - artykuły przemysłowe różne & 1,6 & 1,5 & 1,9 & 2,5 \\
\hline - produkty gdzie indziej niesklafisykowane & - & - & - & - \\
\hline II. Produkty wysokiej i średnio-wysokiej techniki & 50,5 & 48,8 & 49,2 & 50,0 \\
\hline - produkty przemysłu chemicznego & 10,9 & 12,6 & 12,5 & 12,2 \\
\hline $\begin{array}{l}\text { - maszyny i urządzenia, sprzęt elektryczny i elektrotech- } \\
\text { niczny }\end{array}$ & 24,1 & 21,7 & 21,9 & 21,9 \\
\hline - sprzęt transportowy & 13,7 & 12,5 & 12,9 & 13,9 \\
\hline $\begin{array}{l}\text { - przyrządy i aparatura, optyczne, fotograficzne, pomiarowe } \\
\text { kontrolne }\end{array}$ & 1,7 & 1,9 & 1,9 & 1,9 \\
\hline - broń i amunicja & 0,1 & 0,1 & 0,0 & 0,1 \\
\hline III. Dzieła sztuki, przedmioty kolekcjonerskie i antyki & 0,3 & 0,6 & 0,5 & 0,4 \\
\hline Razem & 100,0 & 100,0 & 100,0 & 100,0 \\
\hline
\end{tabular}

b)

\begin{tabular}{||l|r|r|r|r||}
\hline \multirow{2}{*}{ Nazwa wyrobu } & \multicolumn{4}{c|}{$\begin{array}{c}\text { Udział w calości eksportu do państw } \\
\text { czlonkowskich UE (w \%) }\end{array}$} \\
\cline { 2 - 5 } & $\mathbf{2 0 0 7}$ & $\mathbf{2 0 1 1}$ & $\mathbf{2 0 1 4}$ & $\mathbf{2 0 1 7}$ \\
\hline \multicolumn{1}{|c|}{1} & 2 & 3 & 4 & \multicolumn{1}{|c||}{5} \\
\hline I. Wyroby niskiej i średnio-niskiej techniki & 53,4 & 54,5 & 55,3 & 53,4 \\
\hline - zwierzęta żywe, produkty pochodzenia zwierzęcego & 3,8 & 3,7 & 4,4 & 4,6 \\
\hline - produkty pochodzenia roślinnego & 1,9 & 1,8 & 2,4 & 2,0 \\
\hline - tłuszcze i oleje & 0,3 & 0,3 & 0,4 & 0,2 \\
\hline - przetwory spożywcze & 4,1 & 5,3 & 6,3 & 7,0 \\
\hline - produkty mineralne & 4,6 & 5,4 & 4,4 & 2,7 \\
\hline - tworzywa sztuczne i kauczuk oraz artykuły z nich & 6,3 & 7,3 & 7,3 & 7,2 \\
\hline - skóry i artykuły z nich & 0,4 & 0,4 & 0,4 & 0,4 \\
\hline - drewno i artykuły z drewna & 2,8 & 2,2 & 2,4 & 2,3 \\
\hline - ścier drzewny, papier, tektura i artykuły z nich & 2,6 & 2,9 & 2,7 & 3,0 \\
\hline - materiały i artykuły włókiennicze & 3,6 & 3,5 & 3,6 & 4,0 \\
\hline - obuwie, nakrycie głowy itp. & 0.3 & 0,3 & 0,5 & 0,8 \\
\hline - artykuły z kamienia, wyroby ceramiczne, szkło & 2,1 & 1,8 & 2,0 & 1,9 \\
\hline - perły, kamienie szlachetne, metale szlachetne i artykuły & 0,6 & 0,9 & $0,6-$ & 0,4 \\
\hline z nich & & & & \\
\hline - metale nieszlachetne i artykuły z nich & 13,3 & 12,3 & 10,9 & 10,2 \\
\hline - artykuły przemysłowe różne & 6,9 & 6,1 & 7,0 & 8,1 \\
\hline - produkty gdzie indziej niesklasyfikowane & - & - & - & - \\
\hline
\end{tabular}




\begin{tabular}{|c|c|c|c|c|}
\hline 1 & 2 & 3 & 4 & 5 \\
\hline II. Produkty wysokiej i średnio-wysokiej techniki & 46,6 & 45,4 & 44,6 & 45,1 \\
\hline - produkty przemysłu chemicznego & 4,4 & 6,1 & 6,6 & 6,8 \\
\hline $\begin{array}{l}\text { - maszyny i urządzenia, sprzęt elektryczny i elektrotech- } \\
\text { niczny }\end{array}$ & 25,7 & 23,6 & 24,1 & 23,0 \\
\hline - sprzęt transportowy & 15,7 & 14,7 & 12,8 & 13,7 \\
\hline $\begin{array}{l}\text { - przyrządy i aparatura, optyczne, fotograficzne, pomiarowe } \\
\text { i kontrolne itp. }\end{array}$ & 0,8 & 1,0 & 1.1 & 1,6 \\
\hline - broń i amunicja & 0.0 & 0,0 & 0,1 & 0,01 \\
\hline III. Dzieła sztuki, przedmioty kolekcjonerskie & 0,0 & 0,1 & 0,1 & 0,0 \\
\hline Razem & 100,0 & 100,0 & 100,0 & 100,0 \\
\hline
\end{tabular}

Źródla: Główny Urząd Statystyczny, Rocznik Statystyczny Handlu Zagranicznego 2008, s. 55-57; 2012, s. 63-65; 2015, s. 65-67; 2018, s. 57-59; Nauka i technika w 2016 r. Aneks VI; obliczenia własne.

Rodzić się tu musi pytanie, jakie czynniki wpłynęły na wysoki udział produktów o wysokiej i średnio-wysokiej technice wśród eksportowanych przez Polskę do Unii towarów. Pytanie to jest tym bardziej uzasadnione, że państwa członkowskie Unii Europejskiej prowadziły w znacznie większym stopniu prace badawcze i rozwojowe niż Polska (patrz tabela 4).

Tabela 4

Udzial ogólnych wydatków krajowych na B+R Polski i 27 państw czlonkowskich UE w produkcie krajowym brutto (w \%)

\begin{tabular}{|c|c|c|}
\hline Rok & Polska & $\begin{array}{c}\text { 27 albo 28 państw } \\
\text { czlonkowskich UE }\end{array}$ \\
\hline 2005 & 0,57 & 1,74 \\
\hline 2008 & 0,60 & 1,77 \\
\hline 2011 & 0,75 & 1,88 \\
\hline 2014 & 0,94 & $1,95^{\mathrm{b}}$ \\
\hline 2016 & 0,97 & $1,99^{\mathrm{b}}$ \\
\hline
\end{tabular}

Wyjaśnienia: a 27 państw członkowskich UE dotyczy lat 2005 i 2008, 28 pozostałych krajów ${ }^{-}$lata 2011, 2014 i 2016; b dane szacunkowe.

Źródła: OECD, Main Science and Technology Indicators, vol. 2011/2, s. 25; Main Science and Technology Indicators. Full database.

Do tych czynników należały bezpośrednie inwestycje zagraniczne oraz import technologii. Bezpośrednie inwestycje były związane w szczególności z wprowadzeniem nowych produktów lub metod wytwarzania. Liczba wykorzystanych zagranicznych licencji wahała się np. w latach 2010-2017 od 1066 do 2740 (Rocznik statystyczny Rzeczypospolitej Polskiej 2018, s. 439).

\section{Saldo w wymianie handlowej między Polską a krajami członkowskimi UE}

Polska wykazywała pozytywne, silnie rosnace saldo w handlu z innymi krajami członkowskimi UE. Zwiększyło się ono z 3076 mln euro w 2007 r. do 40953 mln euro w 2017 r., tzn. o 13,3 raza (patrz tabela 4), co wynikało w szczególności z dodatniej 
relacji eksportu i importu produktów niskiej i średnio-niskiej techniki. Polska eksportowała w dużej mierze te produkty, gdyż ich opracowanie nie wymagało zbyt dużych środków. Saldo Polski w zakresie produktów wysokiej i średnio-wysokiej techniki wzrastało (patrz tabela 4), do czego przyczynił się import przez polskie przedsiębiorstwa zagranicznej technologii oraz BIZ.

Tabela 5

Wielkość salda handlowego Polski z państwami czlonkowskimi Unii Europejskiej

\begin{tabular}{||l|c|c|c|c||}
\hline \multirow{2}{*}{ Nazwa wyrobu } & \multicolumn{3}{c|}{ Wielkość salda handlowego Polski z krajami } \\
& \multicolumn{3}{|c|}{ czlonkowskimi UE } \\
\cline { 2 - 5 } & $\mathbf{2 0 0 7}$ & $\mathbf{2 0 1 1}$ & $\mathbf{2 0 1 4}$ & $\mathbf{2 0 1 7}$ \\
\hline I. Produkty wysokiej i średnio-wysokiej technki & -5183 & 4038 & 8229 & 12629 \\
\hline $\begin{array}{l}\text { W tym: maszyny i urządzenia, sprzęt elektryczny } \\
\text { i elektrotechniczny }\end{array}$ & 1963 & 5403 & 9181 & 10802 \\
\hline II. Produkty niskiej i średnio-niskiej techniki & & 6832 & 21096 & 28715 \\
\hline III. Całkowite saldo & 3076 & 15577 & 28941 & 40953 \\
\hline
\end{tabular}

Wyjaśnienia: ${ }^{\mathrm{a}} \mathrm{w}$ mln euro.

Źródła: Rocznik Statystyczny Handlu Zagranicznego 2008, s. 55, 56 i 57; 2012, s. 63, 64 i 65; 2015, s. 65, 66 i 67; 2018, s. 57, 58 i 59; Nauka i technika w 2016 r. Aneks VI; obliczenia własne.

\section{Zakończenie}

Handel Polski z innymi krajami członkowskimi UE rozwijał się (w cenach stałych) w okresie do 2017 r. mało dynamicznie, na co wpływały niska efektywność działań podejmowanych przez rządy na rzecz pobudzenia koniunktury oraz kryzys strefy euro. W handlu tym szczególną rolę odgrywała Republika Federalna Niemiec, o czym decydowały dwa uwarunkowania. Pierwszym było położenie szczególnego nacisku przez polską gospodarkę na wykorzystanie niemieckich technologii, a drugim - znaczne bezpośrednie inwestycje firm niemieckich na terenie Polski.

Dla handlu Polski z innymi państwami członkowskimi Unii charakterystyczny był istotny udział wyrobów o wysokiej i średnio-wysokiej technice. Silnie narastające pozytywne saldo handlu z tymi państwami wynikało jednak głównie $\mathrm{z}$ handlu produktami o niskiej i średnio-niskiej technice. Niezbędne stawało się zatem istotne zwiększenie (niskiego) udziału wydatków badawczo-rozwojowych w produkcie krajowym brutto. Będzie to zadanie bardzo trudne, gdyż w okresie 2010-2016 Polska zdołała zwiększyć intensywność badawczo-rozwojową jedynie o 0,25\% PKB, a poziom tej intensywności był bardzo niski.

\section{Bibliografia}

Axt H.-J. (2010), Odysee einer Eigendynamik - Wie aus dem Griechlandschock eine Euro-Krise wurde, „Südeuropäische Mitteilungen”, nr 3.

Boysen-Hogrefe J. et al. (2010), Weltkonjunktur und Deutsche Konjunktur im Sommer 2010, "Kieler Diskussionsbeiträge", $\mathrm{nr}$ 481/482.

Budnikowski A. (2006), Międzynarodowe stosunki gospodarcze, Polskie Wydawnictwo Ekonomiczne, Warszawa. 
Deficyt w handllu zagranicznym. Przyczyny - oceny - wnioski, „Nowe Życie Gospodarcze”, nr 3.

Gern K.-J. et al. (2009), Weltwirtschaft im Abwärtsstrudel. Weltkonjunktur im Frühjahr 2009, "Kieler Diskussionsbeiträge", $\mathrm{nr}$ 461/462.

Gern K.-J. et al. (2013), Weltkonjuktur im Frühjahr 2013, “Kieler Diskussionbeiträge”, nr 518/519. Gern K.-J. et al. (2014), Weltkonjuntur im Herbst 2014, "Kieler Diskussionsbeiträge”, nr 543/544.

Główny Urząd Statystyczny, Rocznik Statystyczny Handlu Zagranicznego 2007, 2008, 2009, 2010, 2012, 2015, 2016, 2017 i 2018.

Główny Urząd Statystyczny, Rocznik Statystyczny Rzeczpospolitej Polskiej 2018.

Grundlinien der Wirtschaftsentwicklung im Sommer 2016 (2016), "DIW - Wochenbericht”, nr 24-25.

Kalka P. (2013), The European Union in the Face of the Sovereign Debt Crisis, „Przegląd Zachodni” nr I, p. 152.

Main Science and Technology Indicators. Full database.

Misala J., Pluciński E. (2000), Handel wewnątrzgatęziowy między Polska a Uniq Europejską: teoria i praktyka, Dom Wydawniczy Elipsa, Warszawa.

Narodowy Bank Polski (NBP), Zagraniczne Inwestycje bezpośrednie w Polsce w 2017 r., https:// www.nbp.pl.

Nauka i technika w $2016 r$.

OECD. Main Science and Technology Indicators 2011/2.

\section{Streszczenie}

Celem powyższego artykułu jest przeanalizowanie rozwoju, struktury i salda w handlu Polski z innymi państwami członkowskimi Unii Europejskiej. Autor pokazuje, że handel ten następował (w cenach realnych) stosunkowo powoli i najważniejszym partnerem handlowym Polski w Unii była Republika Federalna Niemiec. Ważną rolę w strukturze rzeczowej handlu odgrywały produkty o wysokiej i średnio-wysokiej technice, pozytywne saldo handlu Polski stanowiło jednak konsekwencję wymiany handlowej w zakresie wyrobów o niskiej i średnioniskiej technice. Niezbędne stało się zatem istotne zwiększenie (niskiego) udziału wydatków badawczo-rozwojowych w produkcie krajowym brutto Polski.

Słowa kluczowe: handel zagraniczny, Polska, kraje członkowskie UE

\section{The trade between Poland and other EU-member countries}

\section{Summary}

The author analyses the trade between Poland and other EU-member countries. His aim is to show the development, structures and the balance of this trade. The author comes to the conclusion that the trade was (in real prices) weak and the Federal Republik of Germany was the most important commercial partner Polands. Although the high technological and technological products played an important role in the trade between Poland and other EU-countries, low technological commodities were the most significant element of the trade balance, It are matters of consequence to increase the $\mathrm{R}+\mathrm{D}$-expenditures in Poland.

Key words: the international trade, Poland, EU-member countries 
